\title{
RESIKO TERJADINYA MIOMA UTERI ANTARA USIA MENIKAH DAN PARITAS
}

\author{
Nurita Nilasari Bunga Kharisma Arifiana Putri \\ Akademi Kebidanan Medika Wiyata \\ Email : nurita@medikawiyata.ac.id
}

\begin{abstract}
Abstrak
Penelitian ini didasarkan oleh adanya perbedaan resiko terjadinya mioma uteri berdasarkan usia menikah dan paritas di Rumah Sakit TK IV Kota Kediri Tahun 2019. Metode penelitian yang digunakan adalah analitik komparasi. Penelitian ini bertujuan untuk mengidentifikasi dan menganalisa perbedaan resiko terjadinya mioma uteri berdasarkan usia menikah dan paritas. Akibat yang dapat ditimbulkan dari mioma uteri adalah terjadinya perdarahan, anemia, dan infeksi, selain itu juga dapat meningkatkan Angka Kematian Ibu (AKI), dengan populasi 117 ibu yang berkunjung ke Poli Kandungan Rumah Sakit TK IV Kota Kediri tahun 2019. Besar sampel adalah 98 ibu yang berkunjung ke Poli Kandungan Rumah Sakit TK IV Kota Kediri, teknik sampel yang digunakan adalah Simpel Random Sampling. Cara pengukuran variable dengan menggunakan lembar pengumpul data. Nilai setiap subyek dikumpulkan dari lembar pengumpul data tersebut dalam bentuk angka dan prosentase. Uji Analisis yang digunakan adalah Chi Square dengan menggunakan aplikasi SPSS. Hasil pada penelitian ini bahwa terdapat perbedaan resiko terjadinya mioma uteri antara faktor usia menikah dengan faktor paritas di Poli Kandungan Rumah Sakit TK IV Kota Kediri dengan hasil $p$ value $\alpha<0,005$ yaitu sebesar 0,000.
\end{abstract}

Kata kunci : Resiko mioma uteri, usia menikah, dan paritas.

\begin{abstract}
This research is based on the difference in risk of uterine myoma based on married age and parity in TK IV Hospital City of Kediri in 2019. The research method used is comparative analytics. This study aims to identify and analyze differences in the risk of uterine myoma based on age of marriage and parity. As a result of uterine myoma is bleeding, anemia, and infection, but it can also increase the maternal mortality rate (MMR), with a population of 117 mothers who visited the Obgyn Examination Room of TK.IV Kediri City in 2019. The sample size was 98 mothers who visited Obgyn Examination Room of TK.IV Kediri City, the sample technique used was Simple Random Sampling. How to measure variables using data collection sheets. The value of each subject is collected from the data collection sheet in the form of numbers and percentages. The Analysis Test used is Chi-Square using SPSS application.The result of this study indicate that there is a difference in the risk of uterine myoma between the age of marriage and the parity factor at Obgyn Examination Room of TK.IV Kediri City with the result of $p$ value $\alpha<0,005$ which is equal to 0,000 .
\end{abstract}

Keywords : Risk of uterine myoma, age of marriage, and parity 


\section{LATAR BELAKANG}

Kesehatan reproduksi merupakan masalah vital dalam pembangunan kesehatan umumnya. Dan tidak akan dapat diselesaikan dengan jalan melakukan tindakan kuratif (pengobatan) tetapi dengan melakukan upaya preventif (pencegahan) dan diagnosa dini (Manuaba, 2000).

Strategi pencegahan dan penanggulangan masalah kesehatan reproduksi harus di lakukan secara terpadu dan tepat dengan menggunakan pendekatan universal supaya cocok diterapkan untuk semua. Beberapa penyakit ginekologi dan gangguan fungsi reproduksi wanita, dalam masyarakat modern yang kini makin kompleks. Mulai masalah infeksi, kista, mioma, kanker leher rahim, penyakit mola, kanker, termasuk kanker payudara, sering terjadi keguguran. Kemandulan dan penyakit lain (Dharmayuda, 2008).

Mioma uteri terjadi sekitar 5\% wanita masa reproduksi (Derek, 2002). Mioma uteri lebih banyak terjadinya pada wanita dengan multipara di bandingkan dengan wanita yang mempunyai riwayat frekuensi melahirkan 1 (satu) dengan 2 (dua) kali (Khashaeva, 2002). Dari penelitian yang dilakukan Hafiz et. al. di Nisthar Hospital Moltan Pakistan mengemukakan bahwa mioma uteri terjadi pada $74 \%$ pasien dengan paritas $1-5$ (multipara) dan $13 \%$ pasien dengan paritas 0 (Nullipara) dengan kata lain sebagian besar pasien mioma uteri terjadi pasien dengan mulltipara (Hafiz el. al 2003).

Berdasarkan penelitian di Amerika Serikat yang dilakukan Schwartz (2004) angka kejadian mioma uteri adalah 2-12 orang per 1000 wanita tiap tahunnya. Schwartz menunjukkan angka kejadian mioma uteri 2-3 kali lebih tinggi pada wanita kulit hitam dibandingkan kulit putih. Di Indonesia mioma uteri di temukan 2,39\%-11,70\% pada semua penderita ginekologi yang dirawat (Hanifa. W. 2005). Menurut penelitian yang dilakukan Karel Tangkudung (1977 dalam Yuad H, 2005) di Surabaya angka kejadian mioma uteri adalah sebesar 10-30\%, sebelumnya di tahun 1974 di Surabaya penelitian yang dilakukan oleh Raharjo (dalam Yuad H, 2005) angka kejadian mioma uteri sebesar 11,87 \% dari semua penderita ginekologi yang dirawat (Yuad. H. 2005). 
Tabel 1 Distribusi Kejadian Mioma Uteri menurut Umur dan Paritas di Poli Kandungan Rumah Sakit TK IV Kota Kediri tahun 2016-2018

\begin{tabular}{|c|c|c|}
\hline Tahun & Jumlah Kunjungan & Jumlah Kejadian Mioma Uteri \\
\hline 2016 & 6616 & $157(2,70 \%)$ \\
\hline 2017 & 6124 & $210(3,43 \%)$ \\
\hline 2018 & 6232 & $376(6,01 \%)$ \\
\hline
\end{tabular}

Sumber : Data Sekunder tahun 2016-2018

Dari tabel 1.1 menunjukkan bahwa kejadian mioma uteri mulai tahun 2016-2018 ada peningkatan sebanyak 2,04\% dan dari tahun 2016-2018 peningkatannya sebanyak 2,49\%.

Kejadian mioma uteri disebabkan oleh beberapa faktor antara lain faktor predisposisi yaitu karakteristik ibu (umur, paritas, sikap, pendidikan), faktor pendukung (hormonal, obesitas, keturunan), faktor pendorong yaitu pelayanan kesehatan (Notoatmodjo, 2005).

Berdasarkan karakteristik ibu, mioma uteri lebih sering terjadi pada usia reproduksi dan jarang ditemukan sebelum menarche dan hanya $10 \%$ pada wanita menopause (Joedasaputra, 2005). Paritas merupakan keadaan seorang wanita sehubungan dengan kelahiran anak yang dapat hidup (Dorland, 2002). Sikap merupakan reaksi atau respon yang masih tertutup dari seseorang terhadap suatu stimulasi atau objek (Notoatmodjo, 2003). Pendidikan, dimana tingkat pendidikan yang tinggi belum tentu mengalami tingkat hubungan dan sikap yang tinggi pula dan begitu sebaliknya.

Dari faktor pendukung yaitu hormonal, mioma uteri dirangsang oleh hormon estrogen yang berlebihan dan berlangsung terus (Manuaba, 2004). Keturunan, wanita dengan garis keturunan tingkat pertama dengan penderita mioma uteri mempunyai 2-3 kali kemungkinan untuk menderita mioma uteri dibandingkan dengan wanita tanpa garis keturunan mioma uteri (Pasker, 2007). Obesitas berperan dalam terjadinya mioma uteri, hal ini berhubungan dengan konvensi hormon androgen menjadi estrogen oleh enzim aramotease di jaringan lemak (Djuantoro, 2000). Dari faktor pendorong yaitu pelayanan kesehatan, dimana metode pelayanan kesehatan yang aktif dan baik dari petugas kesehatan serta keefektifan dan kelengkapan sarana dan prasarana membuat pasien mau melakukan pemeriksaan dini.

Mioma uteri dapat menimbulkan dampak perdarahan, anemia, infeksi atau degenerasi (kistik maupun merah), Mioma subserosa bertangkai kadang tepantir (twisted) yang 
mengakibatkan abdomen akut (Crisdion, M. 2004). Pengaruh mioma uteri pada kehamilan antara lain, menyebabkan infertilitas, kemungkinan abortus bertambah, kelainan letak janin dalam rahim, menghalangi kemajuan persalinan, inersia, dan atonia, uteri, mempersulit lepasnya plasenta dan dapat mengganggu proses involusi dalam masa nifas, tingginya insiden section sesarea.

Sebagai salah satu upaya untuk menurunkan angka kesakitan Ibu karena adanya mioma uteri maka dilakukan upaya penanganan salah satunya dengan melakukan pemeriksaan secara dini, USG, pemeriksaan lab. PA (Crisdiono, M. 2004).

Berdasarkan masalah yang menunjukkan bahwa kejadian mioma uteri di Rumah Sakit TK IV Kota Kediri, maka selama ini upaya yang sudah dilakukan di Rumah Sakit TK IV Kota Kediri untuk terapi konservatif adalah terapi medikamentosa. Preparat yang digunakan untuk terapi medikamentosa adalah analg, GNRH, progesteron, danasol, gestrinon, tamaksifen, geserrelin, antiprostaglandin, dan agen-agen lain. Sedangkan untuk terapi operatif dilakukan apabila mioma uteri lebih besar dari kehamilan 10-12 minggu, tumor yang berkembang cepat, terjadi torsi pada tangkai. Sehingga perlu dilakukan penelitian tentang resiko terjadinya mioma uteri berdasarkan umur dan paritas.

\section{METODE}

Penelitian ini merupakan penelitian Analitik Komparasional dengan menggunakan lembar pengumpul data. Penelitian dilakukan secara cross sectional dengan mengambil subjek untuk meneliti dalam satu waktu yang bersamaan. Sampel yang di gunakan dalam penelitian ini adalah sebagian ibu penderita mioma uteri di Poli Kandungan Rumah Sakit TK IV Kota Kediri, yaitu sebanyak 98 ibu. Instrumen penelitian menggunakan lembar pengumpul data, pengolahan data editing, coding, entri data dan cleasing, analisis data yaitu univariat, dan bivariate, dengan menggunakan uji SPSS Chi-Square. 


\section{HASIL DAN PEMBAHASAN}

Tabel 2 Distribusi Frekuensi terjadinya mioma uteri berdasarkan faktor usia menikah di Poli Kandungan Rumah Sakit TK IV Kota Kediri

\begin{tabular}{ccccc}
\hline No & Kategori & $\begin{array}{c}\text { Faktor Penyebab Usia } \\
\text { Menikah }\end{array}$ & $\mathrm{N}$ & $\%$ \\
\hline 1 & Terjadinya mioma uteri & $<20$ tahun & 46 & 46,94 \\
\hline & $20-35$ ahun & 38 & 38,77 \\
\hline & $>35$ tahun & 14 & 14,29 \\
\hline & & 98 & 100 \\
\hline
\end{tabular}

Berdasarkan tabel 5 dapat diinterpretasikan bahwa sebagian besar responden menikah pada usia $<20$ tahun yaitu sebesar $46(46,94 \%)$ responden. Menikah pada usia di bawah 17 tahun diketahui dapat merangsang tumbuhnya mioma pada organ perempuan, hal ini di sebabkan karena perubahan sel dalam uterus sedang membelah aktif.

Tabel 3 Distribusi Frekuensi karakteristik terjadinya mioma uteri berdasarkan faktor paritas di Poli Kandungan Rumah Sakit TK IV Kota Kediri

\begin{tabular}{ccccc}
\hline No & kategori & $\begin{array}{c}\text { Faktor Penyebab } \\
\text { paritas }\end{array}$ & $\mathrm{N}$ & $\%$ \\
\hline 1 & Terjadinya mioma uteri & Primipara & 22 & 22,46 \\
\hline 2 & & Multipara & 48 & 48,98 \\
\hline 3 & jumlah & grandemultipara & 28 & 28,56 \\
\hline & & 98 & 100 \\
\hline
\end{tabular}

Berdasarkan tabel 6 dapat diinterpretasikan bahwa sebagian besar responden melahirkan lebih dari dua kali yaitu sebesar 48 (48,98 \%) responden. Ibu yang melahirkan melalui jalan lahir lebih dari lima kali kemungkinan besar sebagai pintu masuknya kuman penyakit, hal ini dapat menimbulkan berbagai komplikasi diantaranya mioma uteri 
Tabel 4 Perbedaan Resiko Terjadinya Mioma Uteri Berdasarkan Faktor Usia Menikah dan Faktor Paritas di Poli Kandungan Rumah Sakit TK IV Kota Kediri

\begin{tabular}{|c|c|c|c|c|c|c|}
\hline \multirow{2}{*}{$\begin{array}{c}\text { Resiko Mioma } \\
\text { Uteri }\end{array}$} & \multicolumn{2}{|c|}{ Usia menikah } & \multicolumn{2}{c|}{ Paritas } & \multicolumn{2}{c|}{ Total } \\
\cline { 2 - 7 } & $\mathrm{N}$ & $\%$ & $\mathrm{~N}$ & $\%$ & $\mathrm{~N}$ & $\%$ \\
\hline Beresiko & 30 & 30,60 & 23 & 23,47 & 53 & 54,08 \\
\hline Tidak beresiko & 26 & 26,53 & 19 & 19,38 & 45 & 45,92 \\
\hline Total & 56 & 57,14 & 42 & 42,86 & 98 & 100 \\
\hline
\end{tabular}

Berdasarkan tabel 7 dapat diinterpretasikan bahwa hampir setengahnya $30(30,60 \%)$ faktor usia menikah berisiko mengalami mioma uteri, sedangkan faktor paritas $23(23,47 \%)$ berisiko mengalami mioma uteri.

Dari hasil data penelitian tentang perbedaan resiko terjadinya mioma uteri berdasarkan faktor usia menikah dan factor paritas di Poli Kandungan Rumah Sakit TK IV Kota Kediri, dapat diketahui bahwa sebanyak 56 responden atau 57,14\% beresiko untuk menderita mioma uteri, berasal dari faktor usia menikah (30 atau 30,60\%) dan faktor paritas (23 atau 23,47\%).

Analisis bivariabel dilakukan untuk mengetahui perbedaan antara variabel bebas (Resiko Terjadinya mioma uteri) dengan variabel terikat (Faktor usia menikah dan faktor paritas). Selain itu analisis bivariabel digunakan untuk memprediksi perbedaan yang terjadi. Uji statistik yang digunakan adalah analisis Chi-Square. Hasil analisis bivariabel antara resiko terjadinya mioma uteri dengan faktor usia menikah dan faktor paritas, menunjukkan bahwa faktor usia menikah secara stastik memiliki perbedaan yang bermakna dengan faktor paritas terhadap resiko terjadinya mioma uteri. Mioma uteri adalah neoplasma jinak yang berasal dari otot uterus dan jaringan ikat sehingga dalam kepustakaan disebut juga Leiomioma. Fibromioma atau Fibroid (Mansjoer, Arif.2001). Mioma merupakan tumor yang paling umum pada traktus genetalis yang terdiri atas serabut otot polos yang diselingi dengan untaian jaringan ikat, dan dikelilingi kapsul yang elips (Derek. 2002). Mioma adalah suatu pertumbuhan jinak dari sel otot polos sedangkan untuk otot rahim disebut dengan mioma uteri (Chisdiono, M. 2004).

Menurut Undang-undang RI Nomor 1 Tahun 1974 tentang perkawinan bab II pasal 7 ayat 1 menjelaskan bahwa perkawinan hanya diizinkan jika pihak pria sudah mencapai umur 19 (sembilan belas) tahun dan pihak wanita sudah mencapai umur 16 (enam belas) tahun. Namun peraturan ini banyak dianggap secara eksplisit bertentangan dengan undang-undang RI Nomor 23 Tahun 2002 tentang perlindungan anak bab I pasal 1 ayat 1 menjelaskan bahwa anak adalah seseorang yang belum berusia 18 (delapan belas) tahun, termasuk anak yang masih dalam 
kandungan. Sedangkan pada pasal 16 undang-undang Syuriah dijelaskan bahwa usia kelayakan untuk menikah adalah usia 18 tahun bagi lelaki dengan kalender masehi dan usia kelayakan wanita yaitu usia 17 tahun. Usia menikah yang terlalu muda (di bawah 20 tahun) alat seksual terutama mulut rahim belum cukup kesiapannya untuk berhubungan seksual (Admin CCRC Farmasi UGM. 2009). Jadi dapat disimpulkan bahwa usia menikah minimal 20 tahun. Hal ini dengan memperhatikan beberapa ukuran kedewasaan secara sosial yang banyak ragamnya.

Salah satu penyebab resiko terjadinya mioma uteri, adalah faktor usia menikah, dapat dilihat bahwa bahwa sebagian besar responden menikah pada usia $<20$ tahun yaitu sebesar $46(46,94 \%)$ responden. Menikah pada usia di bawah 17 tahun diketahui dapat merangsang tumbuhnya mioma pada organ perempuan, hal ini di sebabkan karena perubahan sel dalam uterus sedang membelah aktif. Faktor lain yang dapat menyebabkan resiko terjadinya mioma uteri adalah faktor paritas. Dapat dilihat bahwa sebagian besar responden melahirkan lebih dari dua kali yaitu sebesar 48 (48,98\%) responden. Ibu yang melahirkan melalui jalan lahir lebih dari lima kali kemungkinan besar sebagai pintu masuknya kuman penyakit, hal ini dapat menimbulkan berbagai komplikasi diantaranya mioma uteri.

Faktor lain yang dapat menyebabkan resiko terjadinya mioma uteri adalah faktor paritas. Dapat dilihat bahwa sebagian besar responden melahirkan lebih dari dua kali yaitu sebesar 48 $(48,98 \%)$ responden. Ibu yang melahirkan melalui jalan lahir lebih dari lima kali kemungkinan besar sebagai pintu masuknya kuman penyakit, hal ini dapat menimbulkan berbagai komplikasi diantaranya mioma uteri. Dapat diketahui bahwa sebagian besar tidak mempunyai riwayat penyakit mioma uteri sebanyak $64(65,31 \%)$ responden. Sebagian besar pasien dengan riwayat menderita mioma uteri, merupakan pasien dengan perawatan berkelanjutan. Sedangkan pasien tidak memiliki riwayat menderita mioma uteri, yaitu sebanya 64 atau $65,31 \%$ responden merupakan pasien dengan pemeriksaan pertama terhadap mioma uteri tersebut.

\section{KESIMPULAN DAN SARAN}

Berdasarkan hasil penelitian yang telah dilakukan, maka didapatkan kesimpulan bahwa hamper setengahnya yaitu 30 atau 30,60\% ibu penderita mioma uteri mempunyai faktor resiko dari usia menikah. Sebagian kecil yaitu sebanyak 23 atau 23,47\% ibu penderita mioma uteri mempunyai faktor resiko dari paritas.

Terdapat perbedaan resiko terjadinya mioma uteri berdasarkan faktor usia menikah dan faktor paritas di Poli Kandungan Rumah Sakit TK IV Kota Kediri. 


\section{UCAPAN TERIMA KASIH}

Ucapan terima kasih penulis haturkan kepada Institusi Akademi Kebidanan Medika Wiyata Kediri yang telah memberikan fasilitas untuk melakukan penelitian, kepada Institusi Universitas Kadiri Program Studi D-III Kebidanan yang telah memfasilitasi untuk terbitnya artikel penelitian ini, kepada Rumah Sakit TK IV Kota Kediri yang telah memberikan izin untuk melakukan penelitian, serta keluarga, kerabat, dan pihak yang mendukung terselesainya penelitian ini sampai dengan terbitnya artikel penelitian ini.

\section{DAFTAR PUSTAKA}

Achadiat, CM. 2004. Prosedur Tetap Obstetri dan Ginekologi. Jakarta : EGC.

Arikunto, Suharsini. 2006. Prosedur Penelitian Suatu Pendekatan Praktik. Jakarta : Rineka Cipta.

Budijanto, Didik dan Prajogo. 2005. Metodologi Penelitian. Surabaya : Unit Penelitian dan Pengabdian Masyarakat Politeknik Kesehatan Surabaya.

Derek LJ. 2002. Dasar-dasar Obstetri dan Ginekologi Edisi Ke-6. jakarta : Hipokrates.

Hafiz R, Ali M. Ahmad M. 2003. Fibroids as a Causative Factoriln Menorrhagia and its management. www.yayanakthyar.wordspress.com

Hanifa, Winkjosastro. 2005. ilmu Kandungan. Jakarta : Yayasan Bina Pustaka Sarwono Prawirohardjo.

Hidayat A. Aziz Alimul. 2007. Metodologi Penelitian Kebidanan Teknik Analisis Data. Jakarta : EGC.

Khashaeva. 1992. Incidence of Gynekologic Disease in Multiparal During the Climacteric Period. www.yayanakthyar.wordpress.com

Manuaba, IBG. 1998. Ilmu Kebidanan Penyakit Kandungan dan Keluarga Berencana. Jakarta : EGC.

Manuaba, IBG. 1999. Memahami Kesehatan Reproduksi Wanita. Jakarta : EGC.

Manuaba, IBG. 2004. Penuntun Kepaniteraan Klinik Obstetri dan Ginekologi Edisi 2. Jakarta : EGC.

Mansjoer, Arif. 2001. Kapita Selekta Kedokteran. Jakarta : Media Aeculapius.

Notoatmodjo, Soekidjo. 2005. Metode Penelitian Kesehatan. Jakarta : Rineka Cipta.

Notoatmodjo, Soekidjo. 2003. Pendidikan dan Perilaku Kesehatan. Jakarta : Rineka Cipta. 
Nursalam dan Siti Pariani. 2001. Metodologi Penelitian. Jakarta : CV. Infomedia.

Setiadi. 2007. Konsep dan penulisan Riset Keperawatan. Yogyakarta : Graha Ilmu.

Tjokakarda Gde Dharmayuda, 2008. www.bisnisbali.com

Yuad, H. 2005. Miomektomi pada Kehamilan. Bagian Obstetri dan Ginekologi Fk UNAND/RSUP M. Jamil Padang. www.yayanakthyar.wordspress.com 